\title{
The Influence of Behavioral Factors in Making Investment Decisions and Performance: Study on Investors of Colombo Stock Exchange, Sri Lanka
}

\author{
Lingesiya Kengatharan (Corresponding author) \\ Dept. of Financial Management, University of Jaffna, Sri Lanka \\ Tel: 94-21-205-2075Ｅ-mail:lingesiya@yahoo.com
}

Navaneethakrishnan Kengatharan

Dept. of Human Resource Management, University of Jaffna, Sri Lanka

Tel: 94-21-205-2075Ｅ-mail:nkenga@gmail.com

Received: Nov. 8, 2013 Accepted: January 25, $2014 \quad$ Published: June 1, 2014

doi:10.5296/ajfa.v6i1.4893 URL: http://dx.doi.org/10.5296/ajfa.v6i1.4893

\begin{abstract}
The main objective of this study is exploring the behavioral factors influencing individual investors' decisions at the Colombo Stock Exchange. Furthermore, the relations between these factors and investment performance are also examined. As there are limited studies about behavioral finance in Sri Lanka, this study is expected to contribute significantly to the development of this field in Sri Lanka. The study begins with the existing theories in behavioral finance, based on which, hypotheses are proposed. Then, these hypotheses are tested through the questionnaires distributed to individual investors at the Colombo Stock Exchange. The collected data are analyzed by using SPSS. The result shows that there are four behavioral factors affecting the investment decisions of individual investors at the Colombo Stock Exchange which are Herding, Heuristics, Prospect and Market. Most of the variables from all factors have moderate impacts whereas anchoring variable from heuristic factor has high influence and choice of stock variable from herding factor has low influence on investment decision.

This study also tries to find out the influence of behavioral factors on investment performance. Among the behavioral factors mentioned above, only three variables are found to influence the investment performance: choice of stock has negative influence which is from herding
\end{abstract}


factor. Over confidence from heuristics factor has negative influence on investment performance. Anchoring from heuristics factor has positive influence on investment performance. All other variables which are volume of stock, buying and selling and speed of herding variables of herding factor, loss aversion and regret aversion variables of prospect factor and market information and customer preference variables of market factor do not have influence on investment performance.

Keywords: Behavioral finance, Behavioral factors influencing investors' decisions, Investment performance 


\section{Introduction}

Decision-making is a complex process which includes analysis of several factors and following various steps. Investors' decisions are derived from complex models of finance. These models include those based on expected risk and return associated with an investment, and risk-based asset pricing models like CAPM (Capital Asset Pricing Model). But decisions should never be made only by relying on the personal resources and complex models, which do not consider the situational factors. Situational factors are extended not only to the problem faced by the decision maker, but also to the environment. So, in order to make appropriate decision, one needs to analyze the variables of the problem by mediating them applying cognitive psychology. Professional managers are now expected to play a role in: "challenging conventional assumptions of doing business, identifying risks, and seizing opportunities; integrating sustainability issues into strategy, operations, and reporting; redefining success in the context of achieving sustainable value creation; establishing appropriate performance goals and targets; encouraging and rewarding the right behaviors; and ensuring that the necessary information, analysis, and insights are available to support decision making” (IFAC, 2011, p.6).

Decision making can be defined as the process of choosing a particular alternative from a number of alternatives. It is an activity that follows after proper evaluation of all the alternatives. Hence, decision makers need to keep themselves up-to-date by obtaining information/knowledge from diversified fields so that they can accomplish the tasks they have to work upon.

\subsection{Problem statement}

The decisions of investors on stock market play an important role in determining the market trend, which then affects the economy. To understand and provide an appropriate explanation for the investors' decisions, it is important to explore which behavioral factors influencing the decisions of investors at the Colombo Stock Exchange (CSE) and how these factors influence their investment performance. It will be useful for investors to understand common behaviors, from which justify their reactions for better returns. Security organizations may also use this information for better understanding about investors to forecast more accurately and give better recommendations. Thus, stock price will reflect its true value and Colombo stock market becomes the yardstick of the economy's wealth and helps enterprises to raise capital for production and expansion.

To get the research objectives, some questions are raised during the study. The study is done through answering these following questions:

1. What are the behavioral variables influencing individual investment decision makers at the CSE and which factors do they belong to?

2. At which impact levels (if any) do the behavioral factors influence the individual investment decisions at the CSE? 
3. At which impact levels (if any) do the behavioral factors influence the investment performance of investors at the CSE?

\subsection{Significance of the study}

Sri Lanka is an emerging economy in Asia with different ethnicity and many cultural (Sinhalese, Tamil, Muslims and Burgers) characteristics similar to other Asian countries. This research will provide an overview of behavioral finance in Asia when comparing with western culture based on empirical findings and the importance of behavioral finance in Asia in general and in Sri Lanka in particular.

Present study focuses on individual investors within the border of Sri Lanka. In 2012, Sri Lankan economy recorded an impressive growth of 7.2 per cent. It shows burgeoning growth after ended 30 years lasting civil war in May 2009 and moves to a higher sustainable growth path. All key sectors of the economy demonstrated a commendable performance in 2012, underpinned by the peaceful domestic environment, improved investor confidence, favorable macroeconomic conditions, and gradual recovery of the global economy from one of the deepest recessions in history (Central Bank of Sri Lanka , 2012). Sole proprietorship, partnership, companies and small business have been directly and indirectly contributing to economic growth and its sustainability. In boosting economic condition, all the business entities will flourish.

Sri Lanka is an island located very close to India, having a length of $435 \mathrm{~km}$ and width of 225 $\mathrm{km}$ and thus generating total area is $65610 \mathrm{sq} \mathrm{km}$. Sri Lankan population is 20,451,826 and was a peaceful country before its devastating civil war in July 23, 1983. However, very recently, civil war came to end on 18 May 2009 and consequently widespread development has been taking place. Sri Lankan past 30 years war has seriously affected three generations of this country. Anyone can find ample of examples all over the country and many are still suffering from the loss of lives, limbs and material due to the war, no matter what race or religion they belonged to. Terrorism had been the major cause that hindered Sri Lanka achieving its development goals. However the government has allocated billions of rupees to develop the once war-torn north and east in par with the development taking place in the rest of the country. Improved economic performance, GDP growth, peace, and stability in Sri Lanka has led the IMF to change Sri Lanka's status from "Poverty Reduction and Growth Trust" to "Middle Income Emerging Market," an important landmark as the island nation makes its way down the path of development and reaps the benefits of peace. The improvement in status is expected to further open up international capital markets for the country and bring attention from investors targeting emerging markets with strong projected growth.

Not only local demand for business investment but also foreign heightened interest on investment escalated due to the strategic location of Sri Lanka: close to India and the east-west international sea route. For example, central bank of Sri Lanka said Foreign Direct Investment (FDI) has reached a peak of USD 1.07 billion by December 2011, and the government expects it to rise to USD 1.75 in the year 2012. Sri Lanka is recognized as the most liberalized economy in South Asia, foreign investment is a crucial element representing 
Sri Lankan economic growth. The reasons behind for increasing capital investment are underpinned by peaceful domestic environment, improved investor confidence, favorable macroeconomic conditions, and increased capacity utilization together with expansion of economic activity (Central Bank of Sri Lanka, 2011).

Therefore, nowadays, investment decisions play a vital role than ever before. Thus, this research has been designed to investigate the influence of behavioral factors in investment decisions and performance as emerging market in Sri Lanka. Main purpose of the study, in post war situation, how investors are behaving in making their investment decisions and how such behaviors influencing investors' performance. Additionally, no studies have been carried out in Sri Lanka and thus, studying in unsearched area would be great contribution to existing literature.

\section{Theoretical review for behavioral factors impact the process of investors' decision-making}

Even though finance has been studied for thousands of years, behavioral finance that considers human behavior in the financial world is a fairly new field. Behavioral finance theories, which are based on psychology, trying to understand how emotions and cognitive errors influence behavior of individual investors. In the present scenario, behavioral finance is becoming an integral part of the decision, since it heavily influences the performance of investors. They can be improved by recognizing the prejudices and errors of judgment that all of us are sensitive their performance.

According to Ritter (2003, p.429), behavioral finance is based on psychology which suggests that human decision processes are subject to several cognitive illusions. These illusions are divided into two groups: illusions caused by heuristic decision process and illusions rooted from the adoption of mental frames grouped in the prospect theory (Waweru et al., 2008, p.27). These two categories as well as the herding and market factors are also presented as the following.

\subsection{Heuristic theory}

Heuristics are defined as the rules of thumb, which makes decision making easier, especially in complex and uncertain environments (Ritter, 2003, p.431) by reducing the complexity of assessing probabilities and predicting values to simpler judgments (Kahneman \& Tversky, 1974, p.1124). In general, these heuristics are quite useful, particularly when time is limited (Waweru et al., 2008, p.27), but sometimes they lead to biases (Kahneman \& Tversky, 1974, p.1124; Ritter, 2003, p.431). Kahneman \& Tversky seem to be ones of the first writers studying the factors belonging to heuristics when introducing three factors namely representativeness, availability bias, and anchoring (Kahneman \& Tversky, 1974, p.1124-1131). Waweru et al. also list two factors named Gambler's fallacy and Overconfidence into heuristic theory (Waweru et al., 2008, p.27). 


\subsection{Prospect theory}

Expected Utility Theory (EUT) and prospect theory are considered as two approaches to decision-making from different perspectives. Prospect theory focuses on subjective decision-making influenced by the investors' value system, whereas EUT concentrates on investors' rational expectations (Filbeck, Hatfield \& Horvath, 2005, p.170-171). EUT is the normative model of rational choice and descriptive model of economic behavior, which dominates the analysis of decision making under risk. Nonetheless, this theory is criticized for failing to explain why people are attracted to both insurance and gambling. People tend to under-weigh probable outcomes compared with certain ones and people response differently to the similar situations depending on the context of losses or gains in which they are presented (Kahneman \& Tversky, 1979, p.263). Prospect theory describes some states of mind affecting an individual's decision-making processes including Regret aversion, Loss aversion and Mental accounting (Waweru et al., 2003, p.28).

\subsection{Market factors}

DeBondt \&Thaler (1995, p.396) state that financial markets can be affected by investors' behaviors in the way of behavioral finance. If the perspectives of behavioral finance are correct, it is believed that the investors may have over- or under-reaction to price changes or news; extrapolation of past trends into the future; a lack of attention to fundamentals underlying a stock; the focus on popular stocks and seasonal price cycles. These market factors, in turns, influence the decision making of investors in the stock market. Waweru et al. (2008, p.36) identifies the factors of market that have impact on investors' decision making: Price changes, market information, past trends of stocks, customer preference, over-reaction to price changes, and fundamentals of underlying stocks.

\subsection{Herding effect}

Herding effect in financial market is identified as tendency of investors' behaviors to follow the others' actions. Practitioners usually consider carefully the existence of herding, due to the fact that investors rely on collective information more than private information can result the price deviation of the securities from fundamental value; therefore, many good chances for investment at the present can be impacted. Academic researchers also pay their attention to herding; because its impacts on stock price changes can influence the attributes of risk and return models and this has impacts on the viewpoints of asset pricing theories (Tan, Chiang, Mason \& Nelling, 2008, p.61). In the perspective of behavior, herding can cause some emotional biases, including conformity, congruity and cognitive conflict, the home bias and gossip. Investors may prefer herding if they believe that herding can help them to extract useful and reliable information. Whereas, the performances of financial professionals, for example, fund managers, or financial analysts, are usually evaluated by subjectively periodic assessment on a relative base and the comparison to their peers. In this case, herding can contribute to the evaluation of professional performance because low-ability ones may mimic the behavior of their high-ability peers in order to develop their professional reputation (Kallinterakis, Munir \& Markovic, 2010, p.306). 
In the security market, herding investors base their investment decisions on the masses' decisions of buying or selling stocks. In contrast, informed and rational investors usually ignore following the flow of masses, and this makes the market efficient.Herding, in the opposite, causes a state of inefficient market, which is usually recognized by speculative bubbles. In general, herding investors act the same ways as prehistoric men who had a little knowledge and information of the surrounding environment and gathered in groups to support each other and get safety (Caparrelli et al., 2004, p.223). There are several elements that impact the herding behavior of an investor, for example: overconfidence, volume of investment, and so on. Waweru et al. (2008, p.37) identify stock investment decisions that an investor can be impacted by the others: buying, selling, choice of stock, length of time to hold stock, and volume of stock to trade. Waweru et al. conclude that buying and selling decisions of an investor are significantly impacted by others' decisions, and herding behavior helps investors to have a sense of regret aversion for their decisions. For other decisions: choice of stock, length of time to hold stock, and volume of stock to trade, investors seem to be less impacted by herding behavior. However, these conclusions are given to the case of institutional investors; thus, the result can be different in the case of individual investors because, as mentioned above, individuals tend to herd in their investment more than institutional investors. Therefore, this research will explore the influences of herding on individual investment decision making at the CSE to assess the impact level of this factor on their decisions.

\section{Data and Methodology}

Population of the study was individual investors of CSE. Cross-sectional design is employed in this study. Study fits the nature of this study to describe a common trend of investors' behaviors rather than one specific case, and the data in this study has not been collected in stages but carried out in a single time period. The cross-sectional design allows collecting quantitative data and data synthesized from the questionnaires sent to individual investors of CSE. The data collected from questionnaires provide the basic understandings about the factors affecting investors' decisions .Questionnaires are sent to respondents using stratified random sampling. Initially, convenience sampling was chosen as it is the best technique to get the highest rate of response when sending to friends and relatives. In addition, it would help to save time and money. Nevertheless, convenience sampling is one type of non-probability sampling, which cannot provide representative sample, thus the result cannot be generalized for the whole population (Bryman \& Bell, 2007, p.198) while the target is to find out the financial behaviors of the whole population of individual investors. In contrast, stratified random sampling allows us to stratifying the population by a criterion of the brokerage market share, and then choose random sample or systematic sample from each strata (Bryman \& Bell, 2007, p.187). Stratified sampling ensures that the sample is distributed in the same way as the population (Bryman \& Bell, 2007, p.187). The number of questionnaires sent to each security company through branch managers of CSE. 


\subsection{Design of Measurements and Questionnaire}

The questionnaire is divided into three parts: personal information, behavioral factors influencing investment decisions, and investment performance. The 6-point Likert scales, which are rating scales widely used for asking respondents' opinions and attitudes (Fisher, 2010, p.214), are utilized to ask the individual investors to evaluate the degrees of their agreement with the impacts of behavioral factors on their investment decision as well as with the statements of investment performance. The 6 points in the scale are respectively from 1 to 6: strongly disagree, disagree, no opinion, agree, and strongly agree.

Behavioral factors influencing the investors' decision-making are divided into four groups: heuristic, prospect, market, and herding effect, which are presented in the Table .1.0

Table 1. Behavioral factors influencing the investment decision making

\begin{tabular}{ll}
\hline Theory & Behavioral variables \\
\hline Heuristic Theory & - Representativeness \\
& - Overconfidence \\
& - Anchoring \\
& - Gambler's fallacy \\
& - Availability bias \\
& - Loss aversion \\
& - Regret aversion \\
& - Mental accounting \\
Prospect Theory & - Price changes \\
& - Market information \\
& - Past trends of stocks \\
& - Fundamentals of underlying stocks \\
Market & - Customer preference \\
& - Over-reaction to price changes \\
& - Buying and Selling decisions of other \\
& investors \\
Herding Effect & - Choice of stock to trade of other investors \\
& - Volume of stock to trade of other investors \\
& - Speed of herding \\
\hline
\end{tabular}

Source: Waweru et al., 2008

These groups reflect a total picture of almost behavioral factors can impact the investors' decisions at the stock exchanges. Therefore, they can be used in order to recognize the behaviors of individual or even institutional investors in security trading, regardless of the stock market types: frontier, emerging or developed. Thus, hypotheses are proposed as below: 


\section{Macrothink}

Asian Journal of Finance \& Accounting ISSN 1946-052X 2014, Vol. 6, No. 1

Hypothesis $H_{1}$ : The behavioral variables that influence the investment decisions of individuals at the Colombo Stock Exchange are grouped in four factors as the reviewed theories: Heuristics, Prospect, Market, and Herding.

This hypothesis is tested by exploratory factor analysis to identify which dimensions the behavioral variables belong to.

Hypothesis $\mathrm{H}_{2}$ : The behavioral factors have influence on the investment decisions of individual investors at the Colombo Stock Exchange at high levels.

This hypothesis is tested by synthesizing the respondents' evaluations of influence degrees of behavioral factors on investment decisions.

Hypothesis $\mathrm{H}_{3}$ : The behavioral factors have positive influence on the investment performance of individual investors at the Colombo Stock Exchange.

This hypothesis is tested by using multiple regression analysis that presents the correlation indexes among the behavioral factors and investment performance.

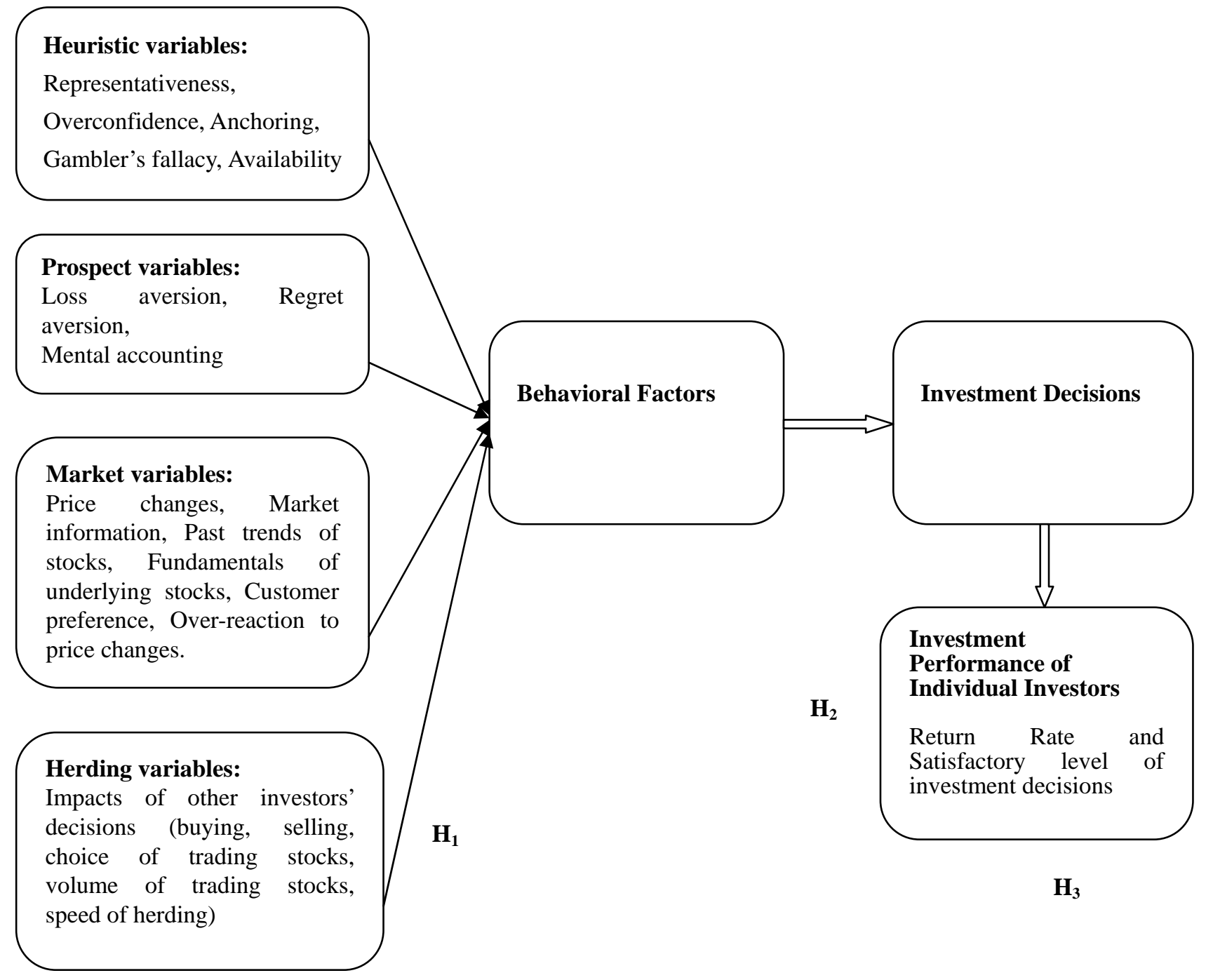

Figure 1. Conceptual framework of the study 


\section{Data process and analysis}

The collected data are processed and analyzed by SPSS. At first, the data are cleaned by removing the questionnaire with poor quality such as including too many missing values or bias ratings. Then, statistical techniques, which are used for the data to achieve the research objectives, include Descriptive Statistics, Factor Analysis, and Multiple Regression Analysis.

To establish reliability and validity of the questionnaire, questionnaire was pre-tested with a 30 sample of investors and finalized before it was utilized for the survey. The Cronbach's alpha was used to measure of reliability random errors. The reliability coefficient of all indicators of industrial performance was 0.843 which indicated the high reliability.

Table 2. Demographic summary of survey responses

\begin{tabular}{|c|c|c|c|}
\hline Title & Category & Number & $\%$ \\
\hline \multirow[t]{2}{*}{ Gender } & Male & 86 & $67.2 \%$ \\
\hline & Female & 42 & $32.8 \%$ \\
\hline \multirow[t]{5}{*}{ Age } & $18-25$ & 41 & $32 \%$ \\
\hline & $26-35$ & 34 & $26.6 \%$ \\
\hline & $36-45$ & 34 & $26.6 \%$ \\
\hline & $46-55$ & 02 & $1.6 \%$ \\
\hline & Over 55 & 17 & $13.3 \%$ \\
\hline \multirow[t]{3}{*}{ Marital status } & Single & 58 & $45.3 \%$ \\
\hline & Married & 70 & $54.7 \%$ \\
\hline & Divorced & - & \\
\hline \multirow{6}{*}{$\begin{array}{l}\text { Educational } \\
\text { Qualification }\end{array}$} & High school \& Lower & 20 & $15.6 \%$ \\
\hline & Undergraduate & 44 & $34.4 \%$ \\
\hline & Bachelor & 18 & $14.1 \%$ \\
\hline & Masters & 14 & $10.9 \%$ \\
\hline & $\mathrm{PhD}$ & - & \\
\hline & Others & 32 & $25 \%$ \\
\hline \multirow[t]{3}{*}{ Years of experience } & Under 5 years & 74 & $57.8 \%$ \\
\hline & 5-10 years & 8 & $6.3 \%$ \\
\hline & Over 10 years & 46 & $35.9 \%$ \\
\hline \multirow[t]{6}{*}{ Average monthly } & $10,000-20,000$ & 48 & $37.5 \%$ \\
\hline & $20,000-30,000$ & 32 & $25 \%$ \\
\hline & $30,000-40,000$ & 38 & $29.7 \%$ \\
\hline & $40,000-50,000$ & 6 & $4.7 \%$ \\
\hline & $50,000-60,000$ & - & - \\
\hline & Over 60,000 & 4 & $3.1 \%$ \\
\hline
\end{tabular}


Amount of

Under 25,000

2014, Vol. 6, No. 1

investment

$\begin{array}{lcc}25,000-50,000 & 26 & 20.3 \% \\ 50,000-75,000 & - & - \\ 75,000-100,000 & 12 & 9.4 \% \\ 100,000-150,000 & 19 & 14.8 \% \\ 150,000-200,000 & 12 & 9.4 \% \\ 200,000-300,000 & 12 & 9.4 \% \\ 300,000-400,000 & 8 & 6.3 \%\end{array}$

Over 400,000

Source: Survey Data

The demographic summary of the results reflected in table 2 . The sample was consisted of 86 male (67.2\%) and 42 female (32.8\%) investors. Age distribution in the sample is categorized as $18-25,26-35,36-45,46-55$, and over 55 . Age range between $18-25$ is highly represented in the sample which was $32 \%$ of the sample of young group. Age ranges between $46-55$ and above 55 was less represented in the sample which were $1.6 \%$ and $13.3 \%$ respectively. Respondents proportion was $26.6 \%$ consisted 26-35 and 36-45years of age range.

In terms of marital status, $54.7 \%$ of investors $(N=70)$ were married and $45.3 \%$ of business operators were not married $(N=58)$. Education level of the investors were categorized into six groups such as High school \& lower, undergraduate, bachelor, master, $\mathrm{PhD}$ degree holders and Other qualification. Highest percentage of the respondents was $34.4 \%$ belonged to undergraduate. Second higher percentage of respondents was $25 \%$ belonged to other education qualification $15.6 \%$ belonged to high school and $14.1 \%$ belonged to bachelor degree. Among the educational qualification, small percentage of respondents was $10.9 \%$ consisted of master degree.

Years of experience in their respected field of the sample is categorized as under 5 Years, $5-10$, and over 10 years. $57.8 \%$ of sample was under 5 years of experience, $46 \%$ of sample was over 10 years of experience, and rest was within 5-10 years of experience in their stock market field. Average monthly income of the participants categorized six groups as stated in the table $1.48 \%$ of the respondents fall into 10,000-20,000 income level and very small percentage of sample $4 \%$ falls into over 60,000 income group. As indicated in the table 1 , $30.5 \%$ of the respondents' investments were under 25,000 and very small \% of the respondents (6.3\%) was into the 300,000-400,000 investment group.

Factor analysis of behavioral variables influencing the individual investment decisions and the variables of investment performance

The 23 questions of the questionnaire are designed to explore the levels of behavioral variables' influence on the individual investment decisions at the CSE. Whereas, three 
questions are created to identify the evaluation of investors about their own investment performance.

The exploratory factor analysis (EFA) is used for the behavioral variables and investment performance to identify the factors which these variables belong to. The requirements of factor analysis are satisfied to reduce the variables. After some rounds of removing the unsuitable variables, the analysis results that the remaining variables are grouped into five factors (four factors of behavioral variables and one factor of investment performance). Here Bartlett's test of Sphericity and the Kaiser-Meyer-Olkin measure of sampling adequacy (George \& Mallery, 2003) are used. A measure of sampling adequacy of 0.630 with a value of Bartlett's test of Sphericity (1546.465) with a high significant level $(\mathrm{P}<0.000)$, indicates the suitability of factor analysis and the results is presented in table 3

Table 3. KMO and Bartlett's Test

$$
\begin{aligned}
& \text { Kaiser-Meyer-Olkin Measure of Sampling } \\
& \text { Adequacy. }
\end{aligned}
$$

Bartlett's Test of

Sphericity

Source: Survey Data

Factor loadings of the items on a factor are greater than 0.5 (with the sample size is 100) ensure that EFA has a practical significance to the analyzed data (Hair et al., 1998, p.111). Eigen value greater than one suggests that the five factors explain a sizable variation contained in the data. Since these five factors have Eigen values greater than one, which together explains a variance of 52.791\%; therefore, the factors confirmed the factorial validity. The table 4 and 5 represents these results. 
Table 4. Factor analysis for behavioral variables and investment performance

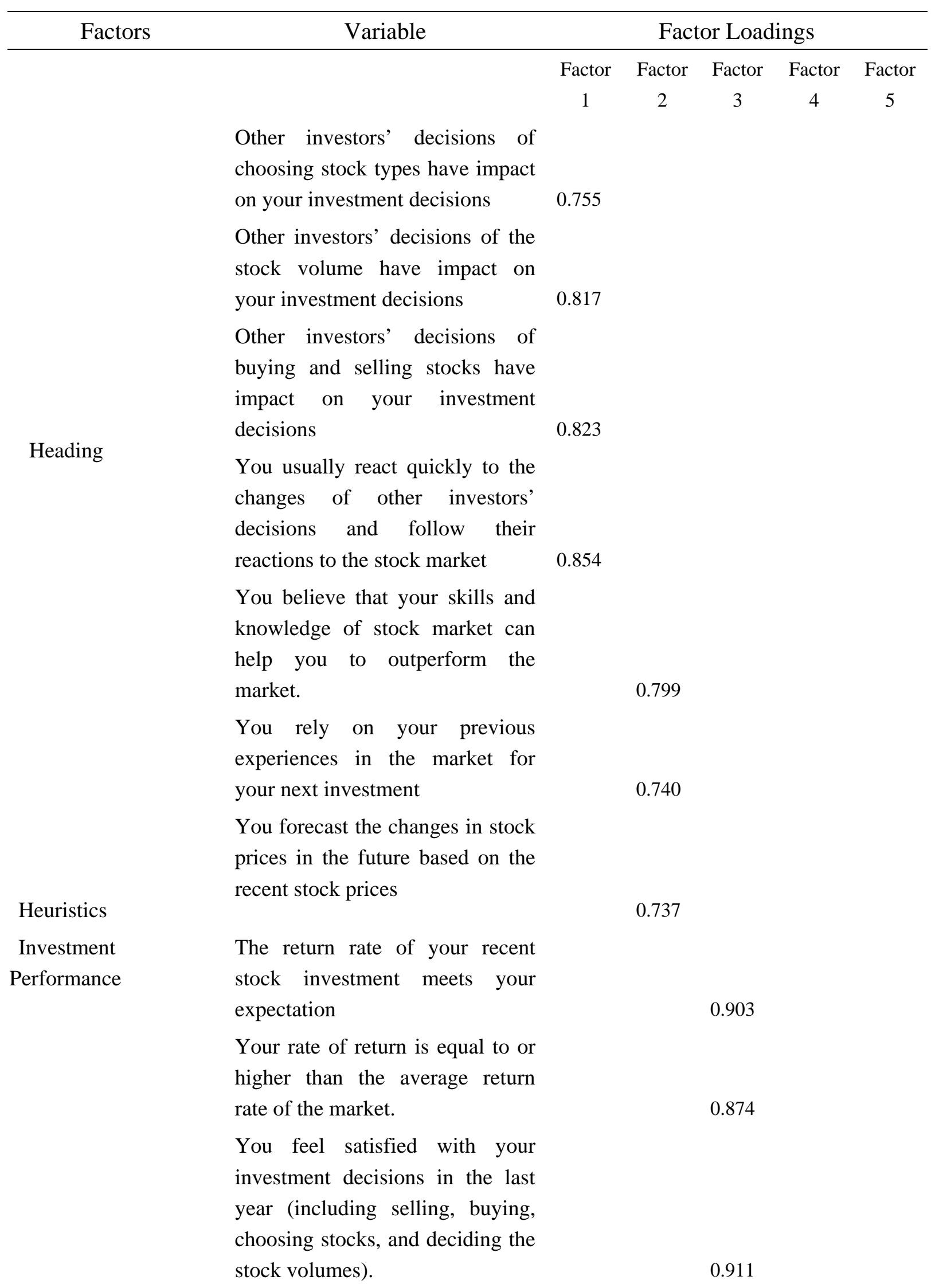


After a prior gain, you are more risk seeking than usual.

Prospect

After a prior loss, you become more risk averse

You avoid selling shares that have decreased in value and readily sell shares that have increased in value.

You have the over-reaction to

Market price changes of stocks

You analyze the companies' customer preference before you invest in their stocks

Extraction Method: Principal Component Analysis. Rotation Method: Varimax with Kaiser Normalization.

Table 5. Total variance explained for factors

\begin{tabular}{lccccc}
\hline & $\begin{array}{c}\text { Herding } \\
\text { (Factor } \\
1)\end{array}$ & $\begin{array}{c}\text { Heuristic } \\
\text { (Factor } \\
\text { 2) }\end{array}$ & $\begin{array}{c}\text { Investment } \\
\text { Performance }\end{array}$ & $\begin{array}{c}\text { Prospect } \\
\text { (Factor }\end{array}$ & $\begin{array}{c}\text { Market } \\
\text { (Factor }\end{array}$ \\
\hline $\begin{array}{l}\text { Eigen Value } \\
\begin{array}{l}\text { Proportion of Variance } \\
\text { explained (\%) }\end{array}\end{array}$ & 4.108 & 3.582 & 2.832 & 2.107 & 1.625 \\
$\begin{array}{l}\text { Cumulative Variance } \\
\text { explained (\%) }\end{array}$ & 15.214 & 13.267 & 10.488 & 7.805 & 6.018 \\
\hline
\end{tabular}

Source: Survey Data

As shown in the Table 5 the variables of herding, heuristics, investment performance, prospect, and market are grouped into related factor. Some of the variables' factor loadings have been removed from the analysis as their factor loadings are less than 0.5. The result illustrates that the behavioral variables that influence the investment decisions of individuals at the CSE are grouped in four factors as the reviewed theories: Herding, Heuristics, Prospect, and Market, and as a result $\mathrm{H}_{1}$ is supported.

As such, there are four behavioral factors that influence the investment decisions of individual investors at the CSE. In the herding factor, all four original variables from the questionnaire are kept after the factor analysis. Only three of eight original items of heuristics are kept by factor analysis, two of six original items of market and three of six original items 
of prospect are accepted by factor analysis. All three original variables investment performance are accepted by factor analysis and all belong to one dimension.

The internal consistency of the items used to measure each factor was calculated using Cronbach's alpha, which is the procedure of choice for investigating the internal consistency of items using Likert-type scale (Walsh \& Betz, 1995). Cronbach's alpha for each factor: factor 1(Herding), factor 2 (Heuristics), factor 3(Investment performance), factor 4(Prospect) and factor 5 (Market) were 0.851, 0.732, 0.897, 0.618 and 0.7 respectively. Since the marginally acceptable reliability should be above 0.60 (Gliner \& Morgan, 2000), this study's all measures are above 0.60 which demonstrates reliability. Therefore the results of reliability analysis confirmed that consistency is at an acceptable level for each factor.

Impact Levels of Behavioral Factors on the Individual Investment Decisions and Scores of Investment Performance

The impact levels of behavioral variables on the investment decisions are identified by calculating the values of sample mean of each variable. Because 6-point scales are used to measure the impact levels of these variables, the mean values of these variables can decide their impact levels on the investment decision making as the following rules:

- Mean values are less than 2 shows that the variables have very low impacts

- Mean values are from 2 to 3 shows that the variables have low impacts

- Mean values are from 3 to 4 shows that the variables have moderate impacts

- Mean values are from 4 to 5 shows that the variables have high impacts

- Mean values are more 5 shows that the variables have very high impacts

Table 6. Impacts of herding variables on the investment decision making

\begin{tabular}{|c|c|c|c|}
\hline Factor & Variables & Mean & St.Deviation \\
\hline \multirow[t]{4}{*}{ Herding } & $\begin{array}{l}\text { Other investors' decisions of choosing stock types } \\
\text { have impact on your investment decisions }\end{array}$ & 2.98 & 0.827 \\
\hline & $\begin{array}{l}\text { Other investors' decisions of the stock volume } \\
\text { have impact on your investment decisions }\end{array}$ & 3.31 & 0.801 \\
\hline & $\begin{array}{l}\text { Other investors' decisions of buying and selling } \\
\text { stocks have impact on your investment decisions }\end{array}$ & 3.06 & 0.821 \\
\hline & $\begin{array}{l}\text { You usually react quickly to the changes of other } \\
\text { investors' decisions and follow their reactions to } \\
\text { the stock market }\end{array}$ & 3.16 & 0.846 \\
\hline
\end{tabular}

Source: Survey data

Choice of stock, volume of stock, buying and selling and speed of herding are the variables of herding that influence the individual's investment decision at CSE. The results are shown in the table 6. Choice of stock variable of herding factor $(\mathrm{M}=2.98)$ has a low impact on 
individual investment decision. And all other three variables of herding factor which are volume of stock, buying and selling and speed of herding have a moderate impact on individual investment decision making as per the result in Table 6.

Table 7. Impacts of heuristics variables on the investment decision making

\begin{tabular}{clcc}
\hline Factor & \multicolumn{1}{c}{ Variables } & Mean & St.Deviation \\
\hline Heuristics & $\begin{array}{l}\text { You believe that your skills and knowledge of } \\
\text { stock market can help you to outperform the } \\
\text { market. }\end{array}$ & & 0.646 \\
& $\begin{array}{l}\text { You rely on your previous experiences in the } \\
\text { market for your next investment }\end{array}$ & & \\
& $\begin{array}{l}\text { You forecast the changes in stock prices in the } \\
\text { future based on the recent stock prices }\end{array}$ & 0.443 & 0.640 \\
\hline
\end{tabular}

Source: Survey data

Over confidence and anchoring are the variables of heuristics factor. Results are shown in the table 1.6. Overconfidence $(\mathrm{M}=3.73)$ has a moderate impact on individual investment decision making. Anchoring: investors rely on their previous experiences in the market for their next investment $(\mathrm{M}=4.16)$ has a high impact on their investment decision making. Anchoring: investors forecast the changes in stock prices in the future based on the recent stock prices $(\mathrm{M}=3.75)$ has a moderate impact on their investment decision

Table 8. Impacts of prospect variables on the investment decision making

\begin{tabular}{|c|c|c|c|}
\hline Factor & Variables & Mean & St.Deviation \\
\hline \multirow{3}{*}{ Prospect } & $\begin{array}{l}\text { After a prior gain, you are more risk seeking than } \\
\text { usual. }\end{array}$ & 3.93 & 0.734 \\
\hline & After a prior loss, you become more risk averse & 3.72 & 0.468 \\
\hline & $\begin{array}{l}\text { You avoid selling shares that have decreased in } \\
\text { value and readily sell shares that have increased in } \\
\text { value. }\end{array}$ & 3.99 & 0.568 \\
\hline
\end{tabular}

Source: Survey data

Loss aversion and regret aversion are the variables of prospect factor. Those variables have a moderate impact on investment decision making. Results are presented in the above table 8. 
Table 9. Impacts of market variables on the investment decision making

\begin{tabular}{|c|c|c|c|}
\hline Factor & Variables & Mean & St.Deviation \\
\hline \multirow{3}{*}{ Market } & $\begin{array}{l}\text { You have the over-reaction to price changes of } \\
\text { stocks }\end{array}$ & 3.60 & 0.523 \\
\hline & & & \\
\hline & $\begin{array}{l}\text { You analyze the companies' customer preference } \\
\text { before you invest in their stocks }\end{array}$ & 3.75 & 0.615 \\
\hline
\end{tabular}

Source: Survey data

Market information and customer preferences are the variables of market factor. According to the result shown in the table 1.8, those two variables have a moderate impact on investment decision making.

In total, most of the behavioral variables of four factors: Herding, Herding, Prospect, and market have moderate impacts on individual investors' decision making at CSE. There is a one item of heuristics factor which is Anchoring: investors rely on their previous experiences in the market for their next investment $(\mathrm{M}=4.16)$ has a high impact on their investment decision making. And there is one item from herding factor which is choice of stock having low impacts $(\mathrm{M}=2.98)$ on investors' decisions. These findings do not support the Hypothesis $\mathrm{H} 2$ that proposes that all factors of behavior finance have high impacts on individuals' investment decisions at CSE.

Influences of Behavioral Factors on the Individual Investment Performance

In order to test the influence of behavioral factors on the individual investment performance hypothesis three has been divided into four parts as follows

Hypothesis $H_{3.1}$ : Variables of herding have a positive influence on investment performance Hypothesis $\mathrm{H}_{3 \cdot 2}$ : Variables of heuristics have a positive influence on investment performance Hypothesis $H_{3.3}$ : Variables of prospect have a positive influence on investment performance Hypothesis $H_{3 \cdot 4:}$ Variables of market have a positive influence on investment performance 
Table 10. Results of Multiple Regression Analysis with investment performance as dependent variable and dimensions of herding factor as predictor variables

\begin{tabular}{|c|c|c|c|c|c|c|}
\hline \multirow[t]{2}{*}{ Model } & \multirow[t]{2}{*}{$\begin{array}{l}\text { independent } \\
\text { Variables }\end{array}$} & \multicolumn{2}{|l|}{$\begin{array}{l}\text { Unstandardized } \\
\text { Coefficients }\end{array}$} & \multirow[t]{2}{*}{$\begin{array}{l}\text { Standardized } \\
\text { Coefficients }\end{array}$} & \multirow[t]{2}{*}{$\mathrm{T}$} & \multirow[t]{2}{*}{ Sig. } \\
\hline & & B & $\begin{array}{l}\text { Std. } \\
\text { Error }\end{array}$ & & & \\
\hline \multirow[t]{5}{*}{1} & (Constant) & 9.878 & .931 & & 10.613 & 0.000 \\
\hline & Choice of stocks & -1.297 & .334 & -.458 & -3.885 & 0.000 \\
\hline & Volume of stocks & .663 & .342 & .236 & 1.940 & 0.055 \\
\hline & $\begin{array}{l}\text { Buying and } \\
\text { selling }\end{array}$ & .496 & .340 & .171 & 1.459 & 0.147 \\
\hline & Speed of herding & .070 & .334 & .025 & .208 & 0.835 \\
\hline \multicolumn{2}{|c|}{$R^{2}=0.113$} & $F=3.934$ & & & & $P=0.005$ \\
\hline
\end{tabular}

Source: Survey Data

The finding of the analysis demonstrates that one dimension of herding factor that choice of stock has negative significant influence on investment performance. Other three dimensions which are volume of stocks, buying and selling, speed of herding have positive impact on investment performance but those are not statistically significant. All for dimensions of herding factor emerged as predictors of investment performance explains together $\left(\mathrm{R}^{2}=.113\right)$ 11.3\% percent of the total variance in investment performance. As the model reveals the remaining $88.7 \%$ of variability is not explained. An Analysis of Variance (ANOVA) indicates that $\mathrm{F}=3.934, \mathrm{p}<0.01$, the model is significant. The results illustrate that herding factor dimensions do not have positive significant influence on investment performance. Therefore hypothesis $\mathrm{H}_{3.1}$ is not supported with the findings as dimensions (variables) of herding factor do not have positive significant influence on investment performance. 
Table 11. Results of Multiple Regression Analysis with investment performance as dependent variable and dimensions of heuristics factor as predictor variables

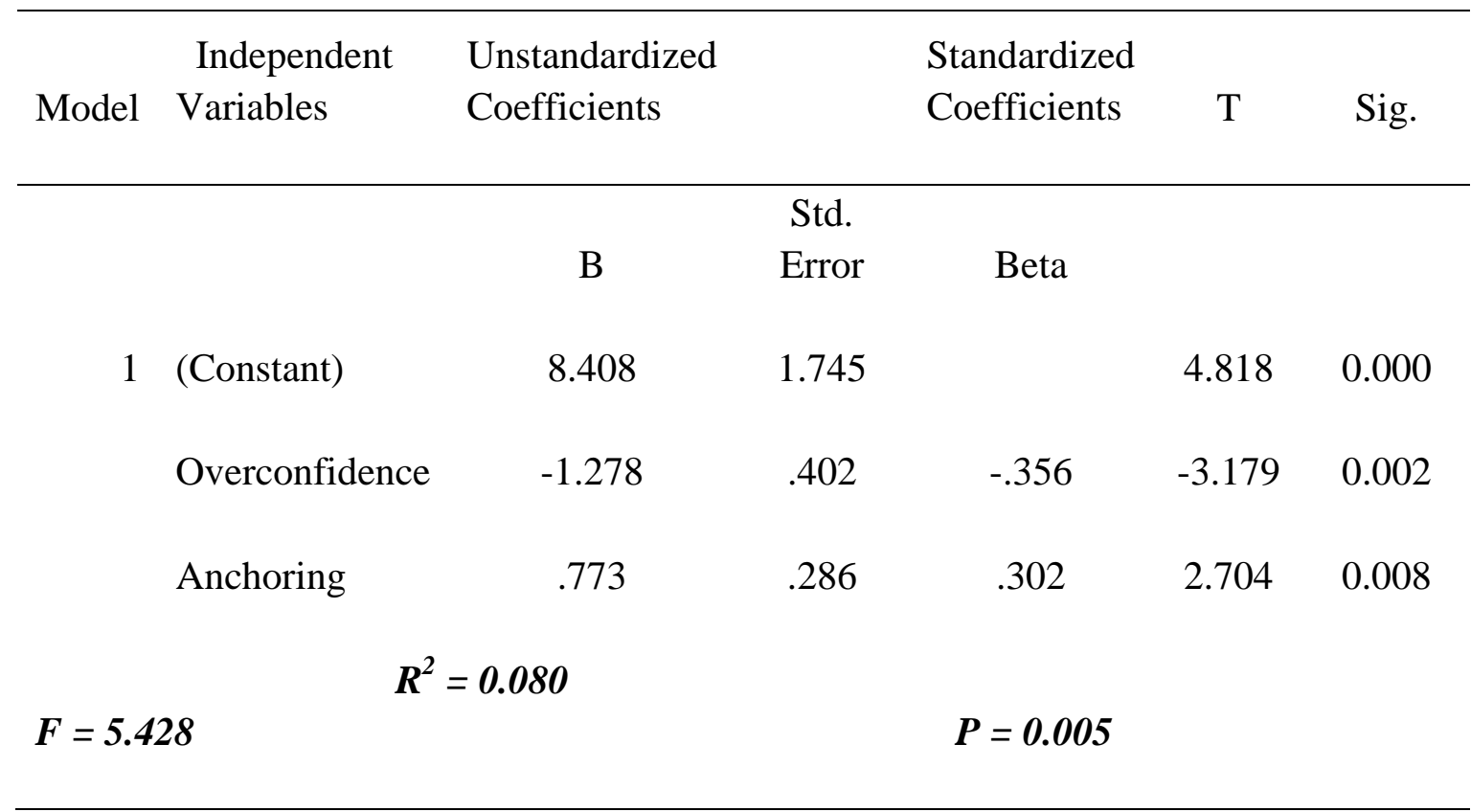

Source: Survey Data

Heuristics factor is composited within the combinations of variables of over confidence and anchoring. The impact of variables of herding factor on investment performance of the individual investors are illustrated in table 1.10. According to the result presented in table 11 overconfidence has negative $(b=-.356, p=0.002)$ significant influence on investment performance whereas anchoring has positive $(b=.302, \mathrm{p}=0.008)$ significant influence on investment performance.

Value of the coefficient of determination of dimensions of herding, which is; $\left(\boldsymbol{R}^{2}\right)$ is 0.080 , whilst this result implies that $8 \%$ percent of the total variance in investment performance, can be explained by all dimensions of heuristics. As the model reveals the remaining $92 \%$ of the variability is not explained. An Analysis of Variance (ANOVA), indicates that; $F=5.428, p<$ 0.01 , that the model is significant. Hypothesis $\left(\mathrm{H}_{3.2}\right)$ states that, variables of heuristics have a positive impact on investment performance. The results illustrate that overconfidence variable of heuristics factor has negative significant impact on performance whereas anchoring has positive impact on investment performance and as a result $\mathrm{H}_{3.2}$ is not supported. 


\section{Macrothink}

Asian Journal of Finance \& Accounting

ISSN 1946-052X

2014, Vol. 6, No. 1

Table 12. Results of Multiple Regression Analysis with investment performance as dependent variable and dimensions of prospect factor as predictor variables

\begin{tabular}{|c|c|c|c|c|c|c|}
\hline Model & $\begin{array}{l}\text { Independent } \\
\text { Variables }\end{array}$ & $\begin{array}{l}\text { Unstandardized } \\
\text { Coefficients }\end{array}$ & & $\begin{array}{l}\text { Standardized } \\
\text { Coefficients }\end{array}$ & $\mathrm{T}$ & Sig. \\
\hline \multirow{4}{*}{1} & & B & Std. Error & Beta & & \\
\hline & (Constant) & 8.557 & 1.817 & & 4.710 & 0.000 \\
\hline & $\begin{array}{l}\text { Loss } \\
\text { aversion }\end{array}$ & -.068 & .208 & -.031 & -.324 & .746 \\
\hline & $\begin{array}{l}\text { Regret } \\
\text { aversion }\end{array}$ & .426 & .386 & .104 & 1.103 & .272 \\
\hline \multicolumn{2}{|c|}{$R^{2}=0.10$} & \multicolumn{2}{|l|}{$F=.610$} & & \multicolumn{2}{|c|}{$P=.545$} \\
\hline
\end{tabular}

Source: Survey Data

Prospect factor is composited within the combinations of variables of loss aversion and regret aversion. The influence of variables of prospect factor on investment performance of the individual investors are illustrated in table 1.11. According to the result presented in table 1.11, those two variables (Loss aversion: $b=-.031, p=0.746$; regret aversion $=.104, p=.272$ ) do not have significant positive influence on investment performance

Hypothesis $\left(\mathrm{H}_{3.3}\right)$ states that, variables of prospect have a positive impact on investment performance. The results illustrate that variables of prospect factor do not have positive significant influence on investment performance as a result $\mathrm{H}_{3.3}$ is not supported. 


\section{Macrothink}

Asian Journal of Finance \& Accounting

ISSN 1946-052X

2014, Vol. 6, No. 1

Table 13. Results of Multiple Regression Analysis with investment performance as dependent variable and dimensions of market factor as predictor variables

$\begin{array}{llllll} & \text { independent } & \text { Unstandardized } & \text { Standardized } & & \\ \text { Model } & \text { Variables } & \text { Coefficients } & \text { Coefficients } & \text { T } & \text { Sig. }\end{array}$

Std.

B Error Beta

1 (Constant) $\quad 8.105 \quad 1.551 \quad 5.227 \quad 0.000$

Market

$\begin{array}{llllll}\text { information } & .386 & .472 & .087 & .818 & .415\end{array}$

Customer

preferences

$.066 \quad .401$

.017

.164

.870

$R^{2}=0.10$

$F=.600$

$P=.550$

Source: Survey Data

Market factor is composited within the combinations of variables of market information and customer preference. The influence of variables of market factor on investment performance is illustrated in table 1.12. According to the result presented in table 13, those two variables (market information: $\mathrm{b}=.087, \mathrm{p}=0.415$; customer preference $=.017, \mathrm{p}=.870$ ) do not have significant positive influence on investment performance

Hypothesis $\left(\mathrm{H}_{3.4}\right)$ states that, variables of market have a positive influence on investment performance. The results illustrate that variables of market factor do not have positive significant influence on investment performance as a result $\mathrm{H}_{3.4}$ is not supported.

\section{Conclusion}

The study is concluded by giving all the answers for the research questions raised in the introduction. This means the research objectives are done and the hypotheses are tested. The following part gives the conclusions for the study by presenting the main points to answer the research questions:

What are the behavioral variables influencing individual investors' decisions at the Colombo Stock Exchange and which factors do they belong to? 
There are four behavioral factors that impact the investment decisions of individual investors at the CSE: Herding, Heuristics, Prospect and Market. The herding factor includes four behavioral variables: choice of trading stocks, volume of trading stocks, buying and selling, and speed of herding). Heuristics factor consists two behavioral variables: over confidence and anchoring. The prospect factor possesses two variables: loss aversion, and regret aversion. The market factor consists of two variables: market information, and customer preferences. Findings suggest that the Hypothesis H1 is supported.

At which impact levels do the behavioral factors influence the individual investors' decisions at the Colombo Stock Exchange?

Most of the mentioned behavioral variables of four factors: Herding (volume of stocks, buying and selling and speed of herding), Heuristics (over confidence), Prospect (loss aversion and regret aversion, and Market (market information and customer preferences) have moderate impacts on individual investors' decision making at CSE. There is one item from herding (choice of stocks) having low impacts on investors' decisions: There is one variable from heuristics (Anchoring) having high impacts on investors' decision. These findings do not support the Hypothesis H2, which proposes that all factors of behavior finance have high impacts on individuals' investment at CSE.

At which impact levels do the behavioral factors influence the investment performance of individual investors at the Colombo Stock Exchange?

Herding: choice of trading stocks have negative significant influence on investment performance; and other three variables of herding volume of trading stocks; buying and selling; and speed of herding do not have impact on performance.

Heuristics: overconfidence has negative significant influence of investment performance whereas anchoring has positive significant influence on investment performance.

Prospect: loss aversion and regret aversion do not have significant influence on investment performance.

Market: market information and customer preferences do not have influence on investment performance. The results do not support the hypothesis H3 that mentions that all behavioral factors have positive impacts on the investment performance.

\section{References}

Bryman, A. \& Bell, E (2011). Business Research Methods, $3^{\text {rd }}$ Edn., Oxford University Press.

Bryman, A. \& Bell, E. (2007) Business Research Methods, $2^{\text {nd }}$ Edn., Oxford University Press.

Caparrelli, F.D., Arcangelis, A.M \& Cassuto, A. (2004). Herding in the Italian stock market: a case of behavioral finance. Journal of Behavioral Finance, 5(4), 222-230. http://dx.doi.org/10.1207/s15427579jpfm0504_5

Central Bank of Sri Lanka (2011) Annual Report, Colombo, Sri Lanka: Available at www.cbsl.lk (Accessed:15.05.2012) 
Central Bank of Sri Lanka (2012) Annual Report, Colombo, Sri Lanka: Available at www.cbsl.lk (Accessed:14.09.2013)

DeBondt, W. F. M. \& Thaler, R. H. (1995). Financial Decision-Making in Markets and Firms: A Behavioral Perspective. Handbooks in Operations Research and Management Science, 9(13), 385-410. http://dx.doi.org/10.1016/S0927-0507(05)80057-X

Filbeck, G., Hatfield, P. \& Horvath, P. (2005). Risk aversion and personality type. Journal of Behavioral Finance, 6(4), 170-180. http://dx.doi.org/10.1207/s15427579jpfm0604_1

Fisher, C. (2010). Researching and writing a dissertation, an essential guide for business students. $3^{\text {rd }}$ Edn., Pearson Eduction Limited.

George, D., \& Mallery, P. (2003). SPSS for Windows step by step: A simple guide and reference. 11.0 update (4th ed.). Boston: Allyn \& Bacon

Gliner,J.A., \& Morgan, G.A. (2000).Research methods in applied settings: an integrated approach to design \& analysis.Morwah, NJ: Lawrence Erlbaum

Hair, J. F., Black, B., Babin, B., Andersion, R. E. \& Tatham, R. L. (1998). Multivariate data analysis. Prentice-Hall, International, Inc.

International Federation of Accountants (IFAC) (2011) 'Sustainability Framework 2.0: Professional Accountants as Integrators' (March 2011).

Kahneman, D. \& Tversky, A. (1974). Judgment under Uncertainty: Heuristics and Biases, Science, 85(4157), 1124-1131.

Kahneman, D. \& Tversky, A. (1979). Prospect theory: an analysis of decision-making under risk'. Econometrica, 47(2), 263-291.

Kallinterakis, V., Munir, N. \& Markovic, M. R. (2010). Herd Behavior, Illiquidity, and Extreme Market States: Evidence from Banja Luka. Journal of Emerging Market Finance, 9, (3), 305-324. . http://dx.doi.org/ 10.1177/097265271000900303

Ritter, J. R. (2003). Behavioral Finance. Pacific-Basin Finance Journal, 11(4), 429-437.

Tan, L., Chiang, T. C., Mason, J. R. \& Nelling, E. (2008). Herding behavior in Chinese stock markets: An examination of A and B shares. Pacific-Basin Finance Journal, 16(1-2), 61-77. http://dx.doi.org/10.1016/j.pacfin.2007.04.004

Walsh, W. B., \& Betz, N. E. (1995). Tests and assessment. (3rd ed.). Englewood Cliffs, N.J.: Prentice Hall.

Waweru, N., M., Munyoki, E., \& Uliana, E. (2008). The effects of behavioral factors in investment decision-making: a survey of institutional investors operating at the Nairobi Stock Exchange. International Journal of Business and Emerging Markets, 1(1), 24-41. http://dx.doi.org/10.1504/IJBEM.2008.019243 